\title{
Mineralogy of Drill Holes J-13, UE-25A\#1, and USW G-1 at Yucca Mountain, Nevada
}

\author{
David L. Bish \\ Steve J. Chipera
}

\section{DISCLAIMER}

This report was prepared as an account of work sponsored by an agency of the United States Government. Neither the United States Government nor any agency thereof, nor any of their employees, makes any warranty, express or implied, or assumes any legal liability or responsibility for the accuracy, completeness, or usefulness of any information, apparatus, product, or process disclosed, or represents that its use would not infringe privately owned rights. Reference herein to any specific commercial product, process, or service by trade name, trademark, manufacturer, or otherwise does not necessarily constitute or imply its endorsement, recommendation, or favoring by the United States Government or any agency thereof. The views and opinions of authors expressed herein do not necessarily state or reflect those of the United States Government or any agency thereof.

\section{MASTER}

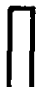


MINERALOGY OF DRILL HOLES J-13, UE-25A\#1, AND USW G-1 AT YUCCA MOUNTAIN, NEYADA

by

David L. Bish and Steve J, Chipera

\begin{abstract}
The mineralogy of drill holes J-13, UE-25A\#1, and USW G-1 was previously determined using qualitative and semiquantitative techniques, and most of the available data were neither complete nor accurate. New quantitative $x$-ray diffraction data were obtained for rocks from all three of these drill holes at Yucca Mountain, Nevada. These quantitative analyses employed both external and internal standard $x$-ray powder diffraction methods and permitted the precise determination of all phases commonly found in the tuffs at Yucca Mountain, including glass and opal-CT. These new data supplant previous analyses and include numerous additional phases. New findings of particular importance include better constraints on the distribution of the more soluble silica polymorphs, cristobalite and opal-CT. Opal-CT was associated solely with clinoptiloite-bearing horizons, and cristobalite disadpearance coincided with the appearance of analcime in USW G-1. Unlike previous analyses, we identified significant amounts of smectite in drill hole $\mathrm{J}-13$. We found no evidence to support previous reports of the occurrence of erionite or phillipsite in these drill holes.
\end{abstract}

\title{
1. INTRODUCTION
}

The mineralogy and petrology of numerous drill holes at Yucca Mountain, Nevada, have been thoroughly investigated as part of a project to determine the suitability of Yucca Mountain to host a geologic repository for high-level radioactive waste. This research, sponsored by the Nevada Nuclear Waste Storage Investigations (NNWSI) Project of the U.S. Department of Energy and directed by the Waste Management Project Office of the Department's Nevada Office of Operations, is concerned with defining the lateral and horizontal variability of the tuffs. The ultimate goal of mineralogy-petrology studies is to obtain a complete three-dimensional model of the Yucca Mountain area, including the candidate repository horizon and the rocks along potential flow 
paths to the accessible environment (Bish and Vaniman 1985). These data are important because the rocks in and around Yucca Mountain will provide the ultimate containment of radioactive waste, and we therefore need a complete understanding of the distribution of potentially sorptive or changeable phases such as zeolites, clays, and glass.

Drill holes J-13, UE-25A\#1, and USW G-1 (Fig. 1) were the first holes thoroughly examined by the NNWSI Project (Heiken and Bevier 1979; Sykes et al. 1979; Bish et al. 1981; Carroll et al. 1981). Mineralogic data for J-13 and UE-25A\#1 were collected using $x$-ray powder camera techniques yielding only qualitative data, and data were not obtained for every sample in these holes. Diffractometer techniques were employed for USW G-1 core and Topopah Spring Member samples from UE-25A\#1, but intensity calibrations were incomplete and only peak heights were used in semiquantitative analysis. Our quantitative analysis techniques have been considerably improved since the first examinations of the mineralogy of J-13, UE-25A\#1, and USW G-1. We now employ a variety of standards and use integrated intensities in our analyses. This report presents quantitative mineralogic analyses for these tinree drill holes as a supplement to the recent summary of Yucca Mountain mineralogy data (Bish and Vaniman 1985). These results differ both qualitatively and quantitatively from earlier results and lead to modified interpretations of mineral distributions and paragenesis.

\section{EXPERIMENTAL TECHNIQUES}

The volcanic rocks at Yucca Mountain commonly have a very fine grained groundmass that is not amenable to quantitative mineral analysis by optical petrographic techniques. Therefore, the data in this report were obtained solely by $x$-ray powder diffractometer techniques. Since our methods are constantly being modified and improved, a discussion of the techniques employed in this report is included here.

The data presented here were obtained on core samples for which accurate depths are given. When available, 15 to $20 \mathrm{~g}$ of core were crushed in a shatterbox to provide a large homogeneous sample. A portion of the powder was ground under acetone in an automatic Brinkmann Retsch mill with agate mortar and pestle to an average particle size of less than $5 \mu \mathrm{m}$. The particle size distribution of several samples was measured using a Horiba CAPA-500 automatic particle size analyzer to ensure that this grinding technique reproducibly 


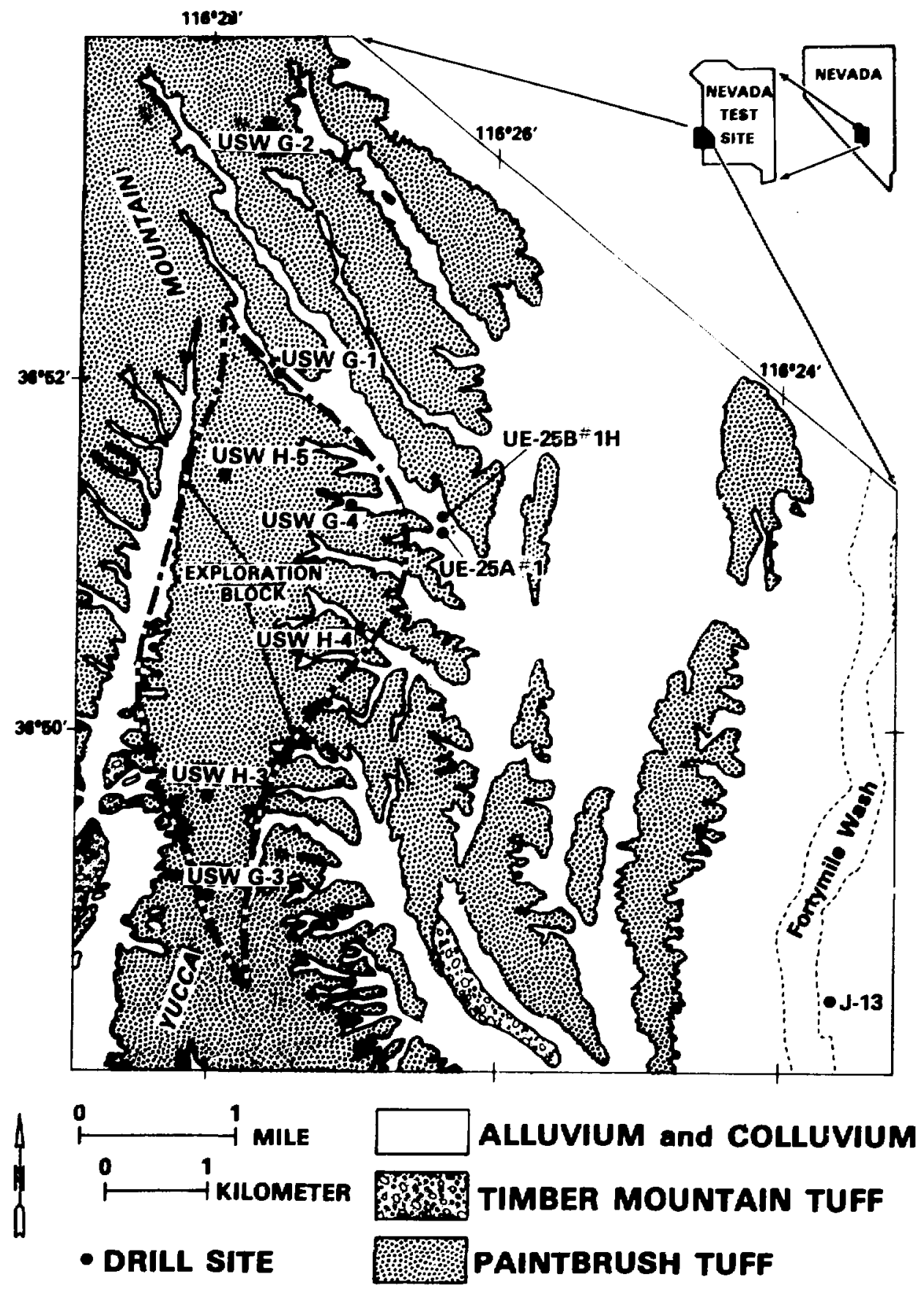

Fig. 1 .

Location map of Yucca Mountain, Nevada, showing the outline of the exploration block for the NNWSI Project and the locations of drill holes mentioned in the text. 
yielded samples with average particle sizes less than 5 um. This fine particle size is necessary to ensure adequate particle statistics and to reduce primary extinction ( $\mathrm{K} l \mathrm{ug}$ and Alexander 1974, pp. 365-367). In addition, a portion of virtually all samples was mixed with $1.0 \mathrm{\mu m}$ corundum powder in the ratio $80 \%$ sample to $20 \%$ corundum; the only exceptions were five samples from 1-13, one sample from UE-25A\#1, and one sample from USW G-1. The resulting powders, both with and without an internal standard, were gently packed into a 22- $x$ 44-mm cavity in a glass slide; this sample area is sufficient to fully contain the $x$-ray beam at the lowest angle of incerest.

All diffraction patterns were obtained on an automated Siemens D-500 diffractometer using copper-Ka radiation, a diffracted-beam monochromator, and pulse-height analysis. Data were collected automatically in the step-scan mode with a step size of $0.02^{\circ} 2 \theta$ and count times of at least $2.0 \mathrm{~s}$ per step. Data were commonly collected from 2.0 to $50.0^{\circ} 2 \theta$ for both pure sampies and samples mixed with corundum.

Mineral identification was accomplished by comparison of observed patterns with patterns of pure standards produced in this laboratory and by comparison with published patterns from the Joint Committee on Powder Diffraction Standards. Clay mineral standards were obtained from the Clay Minerals Society Source $\mathrm{Clay}$ Repository, and zeolite standards were obtained from Minerals Research Corporation, Clarkson, New York. Differentiation between chlorite and kaolinite was accomplished by heating, but admixed smectite and low amounts of chlorite/kaolinite often provided poor distinction. Hematite identification was based on major peaks at $33.2^{\circ}$ and $35.7^{\circ} 2 \theta$. However, overlap with zeolite peaks made the unambiguous determination of the presence of hematite impossible in zeolitized samples. A. Quantitative Analysis

Virtually all of our quantitative analyses employed the internal standard or "matrix-flushing" method of Chung $(1974 a, b)$ and synthetic $1.0 \mathrm{\mu m}$ corundum. Several samples that were too small to be mixed with corundum were analyzed by the external standard method (Chung $1974 \mathrm{a}, \mathrm{b}$ ). Both of these techniques require that reference intensity ratios (RIRs) be determined before sample analysis. We have determined RIRs, the ratio of the integrated intensity of a given reflection of a phase to the integrated intensity of the 113 reflection of corundum in a 1:1 mixture by weight, for most phases found in Yucca Mountain tuffs. RIR values used in our analyses are in Table I, together with 
TABLE I

REFERENCE INTENSITY RATIOS (RIR) FOR MINERALS IN YUCCA MOUNTAIN TUFFS

\begin{tabular}{|c|c|c|c|}
\hline Mineral & Source & $\begin{array}{l}\text { Reflection } \\
\text { hkl or } 2 \theta \text { Range }\end{array}$ & RIR \\
\hline Smectite & $\begin{array}{lll}\text { USW G-1 } & 1415 \\
\text { USW G-1 } & 3490\end{array}$ & $\begin{array}{l}001 \\
001\end{array}$ & $\begin{array}{l}3.85 \\
1.73\end{array}$ \\
\hline Mica & $\begin{array}{l}\text { Avg of calculated } \\
\text { and Bancroft, Ontario }\end{array}$ & $\left(8.8^{\circ}\right)$ & 3.8 \\
\hline Clinoptilolite & $\begin{array}{l}25525 \text { Castle Creek, ID } \\
27032 \text { Castle Creek, ID } \\
27073 \text { Sheaville, OR } \\
27083 \text { Buckhorn, NM } \\
\text { UE4P-1660, Nevada Test Site, NV }\end{array}$ & $\begin{array}{c}020\left(9.8^{\circ}\right) \\
\left(22.4-22.7^{\circ}\right)\end{array}$ & $\begin{array}{l}0.97^{a} \\
1.06\end{array}$ \\
\hline Mordenite & Union Pass, $A Z$ & $\begin{array}{ll}200 & \left(9.8^{\circ}\right) \\
330 & \left(19.6^{\circ}\right) \\
202 & \left(25.7^{\circ}\right)\end{array}$ & $\begin{array}{l}0.556 \\
0.196 \\
0.33\end{array}$ \\
\hline Analcime & Wikieup, $A Z$ & $\begin{array}{ll}211 & \left(15.8^{\circ}\right) \\
400 & \left(26.0^{\circ}\right)\end{array}$ & $\begin{array}{l}1.27 \\
1.80\end{array}$ \\
\hline Quartz & Hot Springs, AR & $\begin{array}{ll}100 & \left(20.8^{\circ}\right) \\
101 & \left(26.6^{\circ}\right)\end{array}$ & $\begin{array}{l}0.86 \\
4.19\end{array}$ \\
\hline Cristobalite & Synthetic Cristobalite & $\begin{array}{ll}101 & \left(21.9^{\circ}\right) \\
200 & \left(36.1^{\circ}\right)\end{array}$ & $\begin{array}{l}4.910 \\
0.843\end{array}$ \\
\hline Tridymite & Nevada Test Site, NV & $\begin{array}{l}\left(20.5^{\circ}\right) \\
\left(21.6^{\circ}\right)\end{array}$ & $\begin{array}{l}1.18 \\
1.10\end{array}$ \\
\hline Opal-CT & $\begin{array}{l}28501 \text { Kl iwikerthal, Czech. } \\
92509 \text { Owyhee County, ID }\end{array}$ & $\left(21 \cdot 0-22.1^{\circ}\right)$ & 1.80 \\
\hline $\begin{array}{l}\text { Feldspar } \\
\text { Albite } \\
\text { Albite } \\
\text { Sanidine } \\
\text { Sanidine }\end{array}$ & $\begin{array}{l}\text { Amelia, VA } \\
\text { Amelia, VA } \\
\text { Eifel, Germany } \\
\text { Eifel, Germany }\end{array}$ & $\begin{array}{l}111\left(13.4-14.0^{\circ}\right) \\
\left(23.6^{\circ}\right) \\
130\left(13.4-14.0^{\circ}\right) \\
\left(23.6^{\circ}\right)\end{array}$ & $\begin{array}{l}0.238 \\
0.274 \\
0.132 \\
0.552\end{array}$ \\
\hline Calcite & Lab Reagent & $\begin{array}{ll}104 & \left(29.4^{\circ}\right) \\
116 & \left(48.5^{\circ}\right)\end{array}$ & $\begin{array}{l}2.958 \\
0.579\end{array}$ \\
\hline Hematite & Calculated & $\begin{array}{l}104\left(33.2^{\circ}\right) \\
110\left(35.7^{\circ}\right)\end{array}$ & $\begin{array}{l}3.188 \\
2.423\end{array}$ \\
\hline Hornblende & Calculated & $110\left\langle 10.4^{\circ} !\right.$ & 0.22 \\
\hline
\end{tabular}

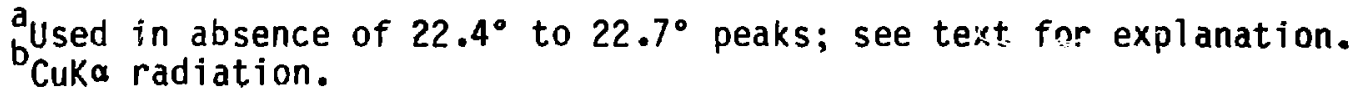


sources of materials. RIRs for several phases were calculated using the program POWD10 (Smith et al. 1982).

All of the measured RIR values for standards are the averages of six repetitions of the same standard-plus-corundum mixture. The RIR for smectite was obtained from material separated from Gl-1415 $(431.3 \mathrm{~m})$, and this RIR was used for most analyses (G1-1415 refers to a sample from drill hole USW G-1 at 1415 $\mathrm{ft}$ depth). However, samples below $1036 \mathrm{~m}$ (3400 ft) in USW G-1 showed evidence for some chlorite interlayers, and the RIR for these samples was obtained from G1-3490 (1063.8 m) smectite. RIRs for clinoptilolite were measured for five different samples to assess the effects of composition and preferred orientation on RIR. We observed an approximately linear relationship between the RIR for the $9.8^{\circ}(020)$ reflection and che intensity ratio of the $9.8^{\circ}$ reflection to the reflections between $22.4^{\circ}$ and $22.7^{\circ} 2 \theta$ (Fig. 2). In our analyses, we commonly used the ratio of the $9.8^{\circ}$ to $22.4^{\circ}$ plus $22.7^{\circ} 2 \theta$ peaks to determine the RIR of the $9.8^{\circ} 2 \theta 020$ reflection and used a fixed RIR for the $22.4^{\circ}$ to $22.7^{\circ} 2 \theta$ cluster. In the absence of a measurable $22.4^{\circ}$ to $22.7^{\circ} 2 \theta$ intensity, we used a value of 0.97 for the $9.8^{\circ} 2 \theta 020$ RIR. The RIRs for mordenite and analcime were measured for natural samples, but we have not assessed the effects of composition on their RIRs. The RIR for tridymite was measured on a rock from Yucca Flat, Nevada Test Site, Nevada, in which tridymite was a major phase. We used RIR values for tridymite that yielded an analysis totaling $100 \%$ for this rock. Thus the tridymite RIR values were not directly measured and are subject to larger errors than are the RIR values for those materials for which we obtained pure samples. The RIR for opal-CT was measured on two natural samples between $21.0^{\circ}$ and $22.1^{\circ} 2 \theta$. The RIRs for alkali feldspar were obtained from natural albite and sanidine for peaks in the range $13.4^{\circ}$ to $14.0^{\circ} 2 \theta$ and at about $23.6^{\circ} 2 \theta$. These peaks are relatively free from interferences from other phases, and if both peaks are used, the relative amounts of both $K$-feldspar and albite can be determined.

All of our analyses employed integrated intensities rather than peak heights; this approach compensates for variations in crystallite size and degree of crystallinity. Integrated intensities were obtained using the Siemens first-derivative peak-search routine that yields precise intensities for rasolved peaks. For overlapping peaks, this routine divides the intensity at ine midpoint between the peaks. Closely overlapping or very broad peaks 


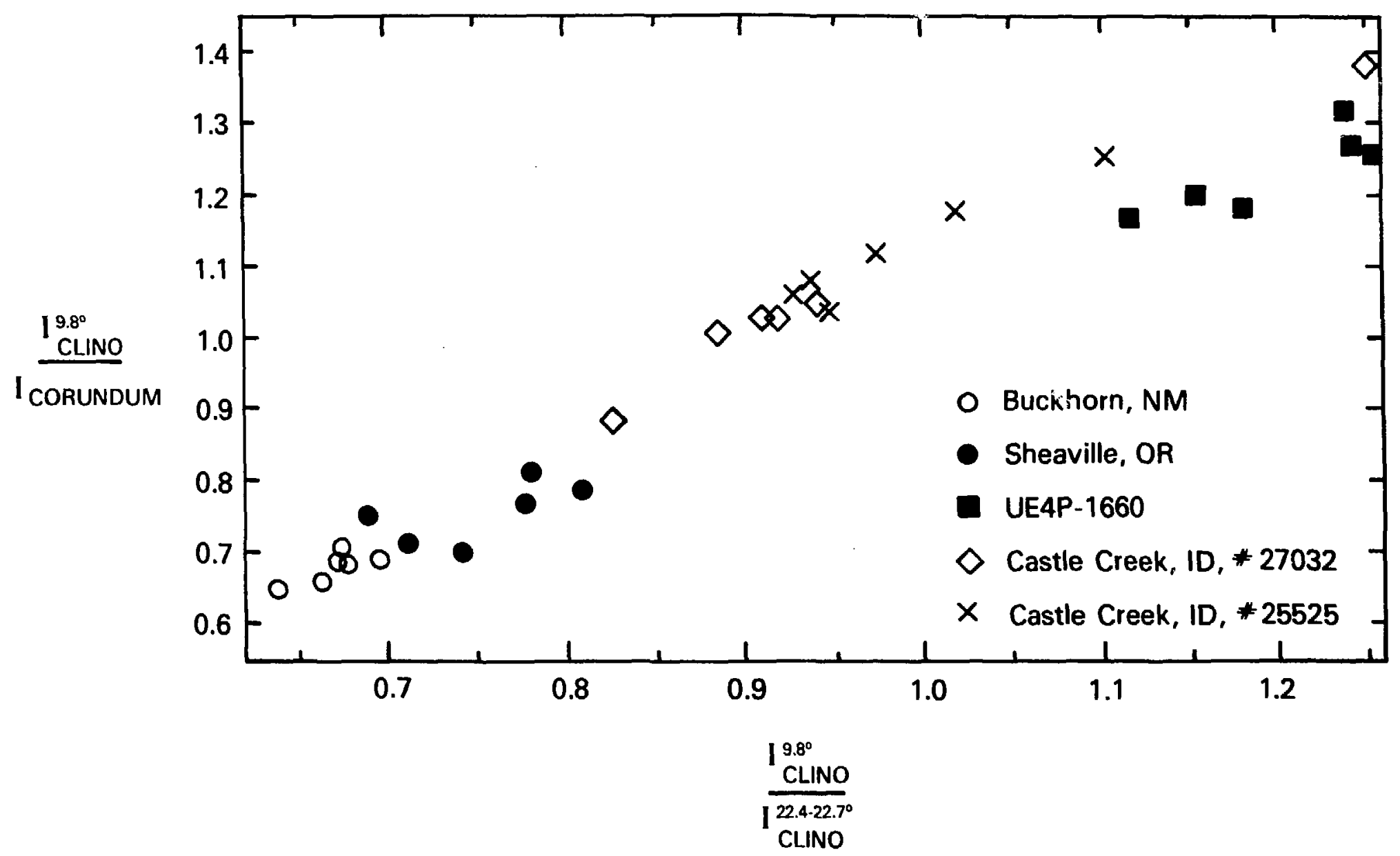

Fig. 2 .

Relationship between the RIR for the $9.8^{\circ}$ clinoptilolite peak and the iritensity ratio of the $9.8^{\circ}$ reflection to the reflections between $22.4^{\circ}$ and $22.7^{\circ}$ (CuKa). 
were measured manually by planimetry, and completely overlapping peaks were not decomposed.

To analyze for the amounts of individual phases, we solved the internal standard equation derived by chung (1974a):

$$
x_{i}=\frac{x_{c}}{K_{i, n}} \frac{I_{i, n}}{I_{c}},
$$

where $x_{i}$ is the weight fraction of component $i, k_{i, n}$ is the RIR for line $n$ of component $i, X_{c}$ is the weight fraction of corundum in the sample (20\%). $I_{i, n}$ is the integrated intensity of 1 ine $n$ of component $i$, and $I_{c}$ is the integrated intensity of the corundum 113 reflection. Note that this method does not require that the sum of the phases be equal to $100 \%$. Amounts of glass in our samples were determined using this method by assuming that the difference between the total. crystalline phases and $100 \%$ was due to glass, There was petrographic evidence for glass in all samples in which we report glass.

We solved the external standard equation derived by Chung (1974b) to analyze the few samples not mixed with corundum:

$$
\ddot{x}_{i}=\left(\frac{K_{i, n}}{I_{i, n}} \sum_{j=1}^{m} \frac{I_{j, n}}{K_{j, n}}\right)^{-1},
$$

where $x_{i}$ is the unknown weight fraction of phase $i$ in the rock, $k_{i, n}$ is the RIR for line $n$ of phase $i, I_{i, n}$ and $I_{j, n}$ are the integrated intensity of 1 ine $n$ of phase $i$ and $j$ respectively, and $m$ is the number of phases in the mixture. This equation differs from equation (1) in that it is derived using the constraint that the sum of all phases equals 100\%. Both equations (1) and (2) "flush" out the absorption coefficients by ratioing the RIRs for each phase. We have coded both the internal and the external standard methods, with all of the appropriate RIRs, in the computer program QUANT4.

QUANT4 has a number of correction routines to compensate for peak over1aps. These include (1) correction of mordenite peaks for overlap with smectite, feldspar, and corundum; (2) correction of cristobalite for overlap with albite; (3) correction of corundum for overlap with calcite; (4) correction of clinoptilolite for overlap with mordenite; and (5) correction of clinoptilolite and opal-CT for mutual overlap. In practice, these corrections improve our accuracy but decrease the precision of our analyses. 


\section{B. Precision of Analyses}

There are numerous sources of variability in our quantitative analyses, some of which can be treated directly and some of which must be approximated. Some of the errors involved are attributable to the sample or to sample preparation. These include crystalline solution, other variations in composition, and preferred orientation. These problems are attributable mainly to differences between samples and standards. Other errors are due to data analysis, such as peak overlap, peak integration, counting statistics, and peak versus background discrimination. Many of these errors cancel or can be determined when measuring RIRs. For example, errors due to preferred orientation will be accounted for if the standard materials exhibit the same degree of preferred orientation as the samples to be analyzed. Errors due to peak integration and peak versus background discrimination are typically similar for sample and standard. However, errors may be significantly increased in

our samples due to the presence of numerous phases with overlapping peaks. In these cases, errors due to partial or complete peak overlap, leading to problems in peak integration, are not accounted for. Therefore, we have written a computer code, RANGE, that takes into account the presence of any combination of phases in the tuff samples and considers the resulting peak overlaps when calculating relative errors. RANGE considers both the errors in RIRs and the presence of overlapping pairs of phases when calculating errors. Included are (1) the effect of the presence of smectite on the relative errors for mordenite; (2) mordenite on clinoptilolite; (3) mordenite on feldspar; (4) feldspar on mordenite; (5) feldspar on cristobalite; (6) clinoptilolite on mordenite; (7) clinoptilolite on quartz; (8) clinoptilolite on feldspar; (9) tridymite on cristobalite; (10) tridymite on feldspar; and (11) opal-CT on clinoptilolite. The resulting relative errors are thus increased by every peak overlap for the sample, and we believe the reported errors for internal standard analyses are conservative. Errors for external standard analyses are typically larger than those inherent in internal standard analyses. The usual reason for employing only external standard analysis was insufficient sample, and in many cases, amounts of samples available were too small to fill our standard sample holders. Therefore, the precision reported for the external standard analyses is not conservative. 
III. MINERAL DISTRIBUTIONS IN ORILL HOLES J-13, UE-25A\#1, AND USW G-1

The mineral distributions in these three holes are similar, and consistent correlations are evident. Tridymite occurs only in shallow samples (shallower than $390 \mathrm{~m}$ ), usually in association with cristobalite and alkali feldspar. Cristobalite al so occurs only in shaliow samples (less than $392 \mathrm{~m}$ ) and disappears as a major phase before the appearance of clinoptilolite in J-13 and UE-25A\#1 and before analcime in USW G-1. Opal-CT coexists with clinoptilolite in all three drill holes, and quartz is the only silica mineral coexisting with analcime in these rocks. Analcime first occurs at $608 \mathrm{~m}$ in $\mathrm{J}-13$ and at $919.9 \mathrm{~m}$ in USW G-1, and clinoptilolite occurs in both holes in the analcime zone. Significant smectite is often associated with glass-bearing zones, and the lower half of USW G-1 contains abundant smectite and interstratified smectite/chlorite.

The results obtained in the present study differ both qualitatively and quantitatively from those obtained previously. Results are most different from the original analyses obtained with a Debye-Scherrer camera (J-13) but are fairly similar to the more recent diffractometer analyses of UE-25A\#1 and USW G-1. Detailed analyses are in Tables II, III, and IV, and Figs. 3, 4, and 5. The distribution of authigenic albite in Fig. 5 is from Bish et al. (1981). Specific differences and details for each drill hole follow.

A. $\mathrm{d}-13$

The original analyses of $\mathrm{J}-13$ were strictly qualitative, obtained with a Debye-Scherrer $x$-ray powder diffraction camera, scanning electron microscope, and electron microprobe (Heiken and Bevier 1979). The present analyses reveal the presence of smectite in most $\mathrm{J}-13$ cores analyzed, up to $20 \%$ in $\mathrm{J13}-1575$ $(480.1 \mathrm{~m})$, whereas the original study did not identify smectite in any samples. Smectite is a particularly important phase because of $i$ ts relatively high cation sorption potential and its low thermal stability (Bish et al. 1982). Also, no tridymite, cristobalite, or opal-CT was identified in the original analyses. These phases are important in understanding mineral reactions with depth (Kerrisk 1983; Bish 1986). The relationship between clinoptilolite and cristobalite in the tuffs supports aqueous silica activity as the controlling variable in the clinoptilolite-to-analcime reaction. In addition to missing the significant amount of smectite in J13-1575 (480.1 m) near the base of the Topopah Spring Member, the previous analysis of this sample also did not report the large amount of glass present. Other minor differences inc: ude 


\section{TABLE II}

$X$-RAY DIFFRACTION ANALYSES OF TUFF FROM DRILL HOLE J-13 (weight percent)

\begin{tabular}{|c|c|c|c|c|c|c|c|c|c|c|c|c|c|c|c|c|}
\hline Samole $\mathrm{e}^{\mathrm{a}}$ & $\begin{array}{l}\text { Oepth } \\
(\mathrm{m})\end{array}$ & Methor ${ }^{b}$ & Smectite & Mica & $\begin{array}{l}\text { Clino- } \\
\text { ptilolite }\end{array}$ & $\begin{array}{l}\text { Morden- } \\
\text { ite }\end{array}$ & $\begin{array}{l}\text { Anal - } \\
\text { cime }\end{array}$ & Ouartz & $\begin{array}{l}\text { Tridy- } \\
\text { mi tee }\end{array}$ & $\begin{array}{l}\text { Cristo- } \\
\text { balite }\end{array}$ & $\begin{array}{l}\text { Opal- } \\
\text { CT }\end{array}$ & Giass & $\begin{array}{l}\text { Alkali } \\
\text { Feldspar }\end{array}$ & Calcite & Hematite & 0ther \\
\hline $\begin{array}{l}\mathrm{J} 13-427 \\
\mathrm{~J} 13-492 \\
\mathrm{~J} 13-591 \\
\mathrm{~J} 13-607 \\
\mathrm{~J} 13-689 \\
\mathrm{~J} 13-801 \\
\mathrm{~J} 13-925 \\
\mathrm{~J} 13-1033 \\
\mathrm{~J} 13-1102 \\
\mathrm{~J} 13-1194 \\
\mathrm{~J} 13-1292 \\
\mathrm{~J} 13-1296 \\
\mathrm{~J} 13-1345 \\
\mathrm{~J} 13-1421 \\
\mathrm{~J} 13-1457 \\
\mathrm{~J} 13-1512 \\
\mathrm{~J} 13-1515 \\
\mathrm{~J} 13-1519 \\
\mathrm{~J} 13-1575 \\
\mathrm{~J} 13-1883 \\
\mathrm{~J} 13-1995 \\
\mathrm{~J} 13-2001 \\
\mathrm{~J} 13-2005 \\
\mathrm{~J} 13-2133 \\
\mathrm{~J} 13-2178 \\
\mathrm{~J} 13-2382 \\
\mathrm{~J} 13-2533 \\
\mathrm{~J} 13-2680 \\
\mathrm{~J} 13-2982 \\
\mathrm{~J} 13-2999 \\
\mathrm{~J} 13-3251\end{array}$ & $\begin{array}{l}130.1 \\
150.0 \\
180.1 \\
185.0 \\
210.0 \\
244.1 \\
281.9 \\
314.9 \\
335.9 \\
364.0 \\
394.0 \\
395.0 \\
410.0 \\
433.0 \\
444.1 \\
460.9 \\
469.0 \\
463.0 \\
480.1 \\
573.9 \\
608.1 \\
609.9 \\
611.1 \\
650.1 \\
663.9 \\
726.0 \\
772.0 \\
816.9 \\
908.9 \\
914.1 \\
990.9\end{array}$ & $\begin{array}{l}I \\
I \\
1 \\
E \\
E \\
I \\
I \\
I \\
I \\
E \\
I \\
E \\
I \\
E \\
I \\
I \\
I \\
I \\
I \\
I \\
I \\
I \\
I \\
I \\
I \\
I \\
I \\
I \\
I \\
I \\
I\end{array}$ & $\begin{array}{c}3 \pm 1 \\
2 \pm 1 \\
T r \\
4 \pm 1 \\
5 \pm 1 \\
20 \pm 4 \\
1 \pm 1 \\
2 \pm 1 \\
2 \pm 1 \\
2 \pm 1\end{array}$ & $\begin{array}{l}\text { Tr } \\
\text { Tr } \\
\text { Tr } \\
2 \pm 1 \\
1 \pm 1 \\
3 \pm 1 \\
2 \pm 1 \\
3 \pm 1 \\
2 \pm 1 \\
1 \pm 1 \\
T r\end{array}$ & $\begin{array}{l}1 \pm 1 \\
\\
\\
\\
27 \pm 3 \\
80 \pm 8 \\
47 \pm 12 \\
64 \pm 6 \\
56 \pm 8 \\
\\
\end{array}$ & $\operatorname{Tr}$ & $\begin{array}{l}43 \pm 2 \\
42 \pm 2 \\
35 \pm 1\end{array}$ & $\begin{array}{l}T r \\
T r \\
1 \pm 1 \\
T r \\
5 \pm 1 \\
1 \pm 1 \\
29 \pm 1 \\
30 \pm 1 \\
20 \pm 1 \\
33 \pm 1 \\
33 \pm 1 \\
36 \pm 1 \\
T r \\
T r \\
2 \pm 1 \\
5 \pm 1 \\
1 \pm 1 \\
7 \pm 1 \\
2 \pm 1 \\
34 \pm 1 \\
33 \pm 1 \\
28 \pm 1 \\
27 \pm 1 \\
32 \pm 1 \\
32 \pm 1 \\
34 \pm 1 \\
32 \pm 1 \\
30 \pm 1 \\
39 \pm 1 \\
36 \pm 1 \\
21 \pm 1\end{array}$ & $\begin{array}{r}15 \pm 1 \\
8 \pm 1 \\
\\
\\
6 \pm 1 \\
2 \pm 1 \\
2 \pm 1 \\
2 \pm 1\end{array}$ & $\begin{array}{r}14 \pm 1 \\
22 \pm 1 \\
\\
7 \pm 1 \\
13 \pm 1 \\
23 \pm 1 \\
3 \pm 1\end{array}$ & $\begin{array}{r}11 \pm 2 \\
25 \pm 5 \\
8 \pm 2 \\
39 \pm 8 \\
12 \pm 2 \\
18 \pm 4\end{array}$ & $\begin{array}{l}94 \pm 1 \\
20 \pm 18\end{array}$ & $\begin{array}{l}70 \pm 13 \\
67 \pm 10 \\
\\
54 \pm 6 \\
66 \pm 10 \\
62 \pm 8 \\
69 \pm 9 \\
78 \pm 10 \\
67 \pm 8 \\
63 \pm 7 \\
64 \pm 8 \\
8 \pm 1 \\
13 \pm 2 \\
7 \pm 1 \\
6 \pm 1 \\
14 \pm 3 \\
13 \pm 2 \\
13 \pm ? \\
67 \pm 8 \\
24 \pm 3 \\
29 \pm 3 \\
31 \pm 4 \\
65 \pm 8 \\
66 \pm 8 \\
33 \pm 4 \\
62 \pm 7 \\
61 \pm 7 \\
56 \pm 7 \\
44 \pm 5 \\
34 \pm 4\end{array}$ & $\begin{array}{l}\text { Tr } \\
\\
\text { Tr } \\
\text { Tr } \\
2 \pm 1 \\
7 \pm 1\end{array}$ & $\begin{array}{l}\text { Tr } \\
\text { Tr } \\
\\
\text { Tr } \\
\text { Tr } \\
\text { Tr } \\
\text { Tr } \\
\text { Tr }\end{array}$ & $1 \pm 1^{\alpha}$ \\
\hline
\end{tabular}

ASamole designation J13-427 refers to a sample from drill hole J-13 at $427 \mathrm{ft}$ depth.

$b_{1}=$ Internal Standard Method, $E=$ External Standard Method.

chornblende.

itcriorite. 
X-RAY DIFFRACTION ANALYSES OF TUFF FRUM DRILL HOLE UE-25A\#I (weight percent)

\begin{tabular}{|c|c|c|c|c|c|c|c|c|c|c|c|c|c|c|c|}
\hline Sample ${ }^{\mathbf{a}}$ & $\begin{array}{l}\text { Depth } \\
\text { (m) }\end{array}$ & Method ${ }^{b}=$ & Smectite & Mica & $\begin{array}{l}\text { Clino- } \\
\text { ptilolite }\end{array}$ & $\begin{array}{l}\text { Morden- } \\
\text { ite }\end{array}$ & Quartz & $\begin{array}{l}\text { Tridy- } \\
\text { mite }\end{array}$ & $\begin{array}{l}\text { Cristo- } \\
\text { nalite }\end{array}$ & $\begin{array}{l}\text { Opal - } \\
\mathrm{CT}\end{array}$ & Glass & $\begin{array}{l}\text { Alkali } \\
\text { feldspar }\end{array}$ & Calcite & Mematite & Kaolinite \\
\hline 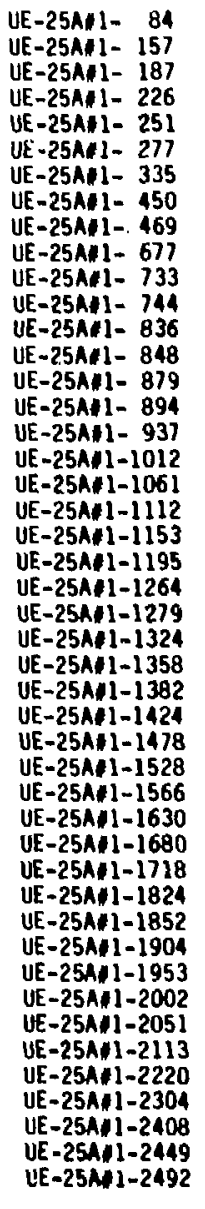 & $\begin{array}{l}25.6 \\
47.9 \\
57.0 \\
69.9 \\
76.5 \\
84.4 \\
102.1 \\
137.2 \\
143.0 \\
206.4 \\
223.4 \\
226.8 \\
254.8 \\
258.5 \\
267.9 \\
272.5 \\
285.6 \\
308.5 \\
323.4 \\
338.9 \\
351.4 \\
364.2 \\
385.3 \\
389.8 \\
403.6 \\
413.9 \\
421.2 \\
431.0 \\
450.5 \\
465.7 \\
477.3 \\
496.8 \\
512.1 \\
523.6 \\
556.0 \\
564.5 \\
580.3 \\
595.3 \\
610.2 \\
625.1 \\
644.0 \\
676.7 \\
702.3 \\
734.0 \\
746.5 \\
759.6\end{array}$ & $\begin{array}{l}1 \\
1 \\
1 \\
1 \\
1 \\
1 \\
1 \\
1 \\
1 \\
1 \\
1 \\
1 \\
1 \\
1 \\
1 \\
1 \\
1 \\
1 \\
1 \\
1 \\
1 \\
1 \\
1 \\
1 \\
1 \\
1 \\
1 \\
1 \\
1 \\
1 \\
1 \\
1 \\
1 \\
1 \\
1 \\
1 \\
1\end{array}$ & 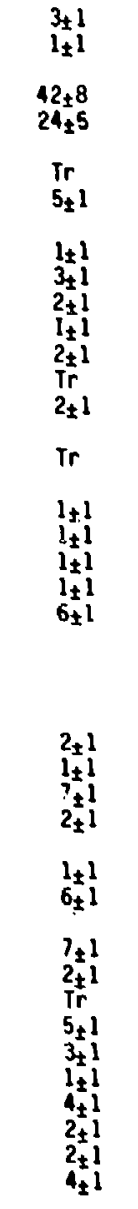 & $\begin{array}{l}2 \pm 1 \\
2 \pm 1 \\
1 \pm 1 \\
1 \pm \\
\mathrm{Ir} \\
\mathrm{Tr} \\
\mathrm{Tr} \\
\mathrm{Tr} \\
\mathrm{Tr} \\
\mathrm{Tr} \\
\mathrm{Tr} \\
\mathrm{Tr} \\
\mathrm{Tr} \\
\mathrm{Tr} \\
\mathrm{Tr}\end{array}$ & $\begin{array}{l} \\
3 \pm 1 \\
3 \\
5 \pm 1 \\
30_{ \pm} ! 2 \\
69_{ \pm} 17 \\
30_{ \pm} 18 \\
70_{ \pm} 14 \\
63_{ \pm} 7 \\
35_{ \pm} 11 \\
38_{ \pm} 5 \\
68_{ \pm} 12 \\
66_{ \pm} 14 \\
45_{ \pm} 12 \\
18_{ \pm} !\end{array}$ & $\begin{array}{r}6 \pm 2 \\
10 \pm+2 \\
43_{ \pm} 8 \\
9 \pm 2 \\
9_{ \pm} 2 \\
21_{ \pm} 5 \\
1 \mathbf{1 r} \\
8_{ \pm} 2 \\
11_{ \pm} 3 \\
15_{ \pm} 4\end{array}$ & 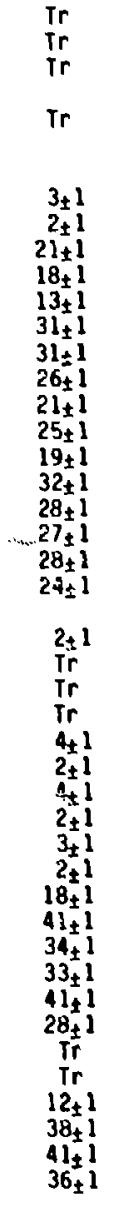 & $\begin{array}{l}8_{ \pm 1} 1 \\
7 \pm 1 \\
8_{ \pm} 1 \\
z_{ \pm} 1 \\
\mathrm{Tr}\end{array}$ & 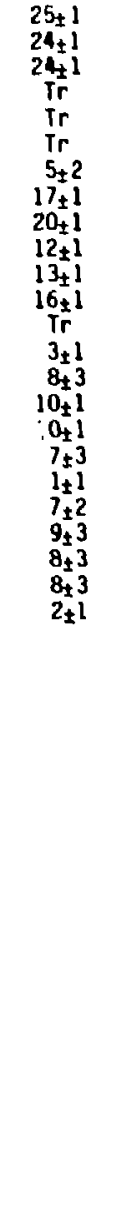 & $\begin{array}{l}6 \pm 1 \\
17 \pm 3 \\
21 \pm 4 \\
17_{ \pm} \\
23+5 \\
211_{4}^{4} \\
29 \pm 6 \\
14_{ \pm} \\
1 \pm_{ \pm} \\
20_{ \pm}\end{array}$ & $\begin{array}{l}36 \pm 9 \\
59 \pm 5 \\
80 \pm 2\end{array}$ & 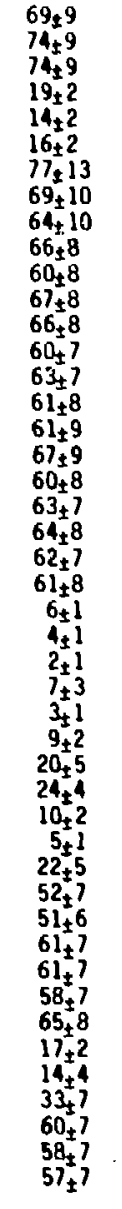 & $\mathrm{Tr}$ & $\begin{array}{l}\text { Ir } \\
\text { Ir } \\
\\
2 \pm 1 \\
1_{ \pm} 1 \\
\text { Ir } \\
l_{ \pm 1} \\
\\
\\
\mathrm{Tr} \\
\mathrm{Tr} \\
\mathrm{Tr} \\
\mathrm{Tr} \\
\mathrm{Tr} \\
\mathrm{Tr} \\
\mathrm{I}_{ \pm} \mathbf{l} \\
\mathrm{Tr} \\
\mathrm{Tr}\end{array}$ & $\begin{array}{l}1 \\
1_{ \pm} \\
1\end{array}$ \\
\hline
\end{tabular}

"Sample destgnation UE-25ANI-B4 refers to a sample from drill hole UE-25AHI at 84 ft depth.

$b_{1}=$ Internal Standard Method, $E=$ External Standard Method. 


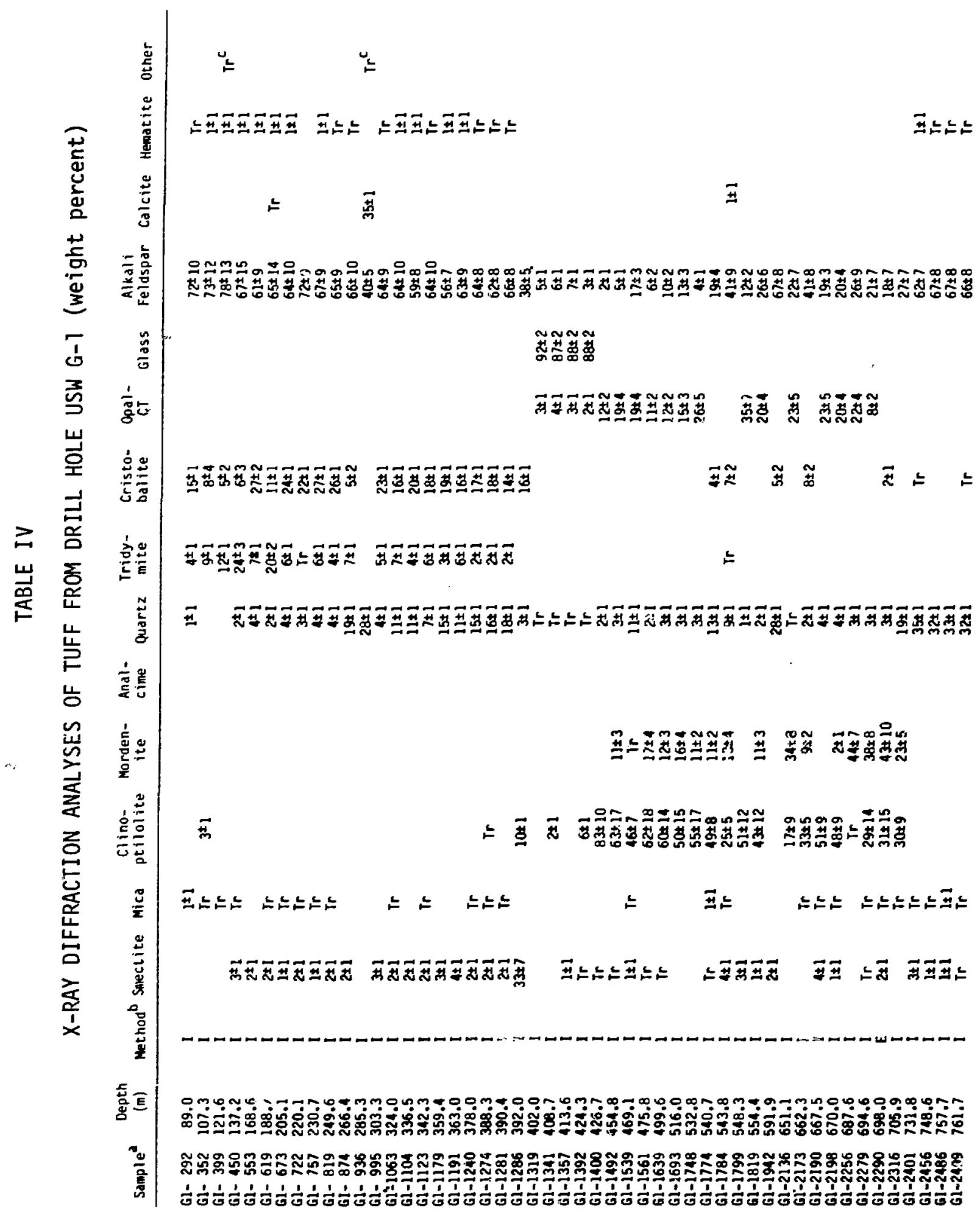




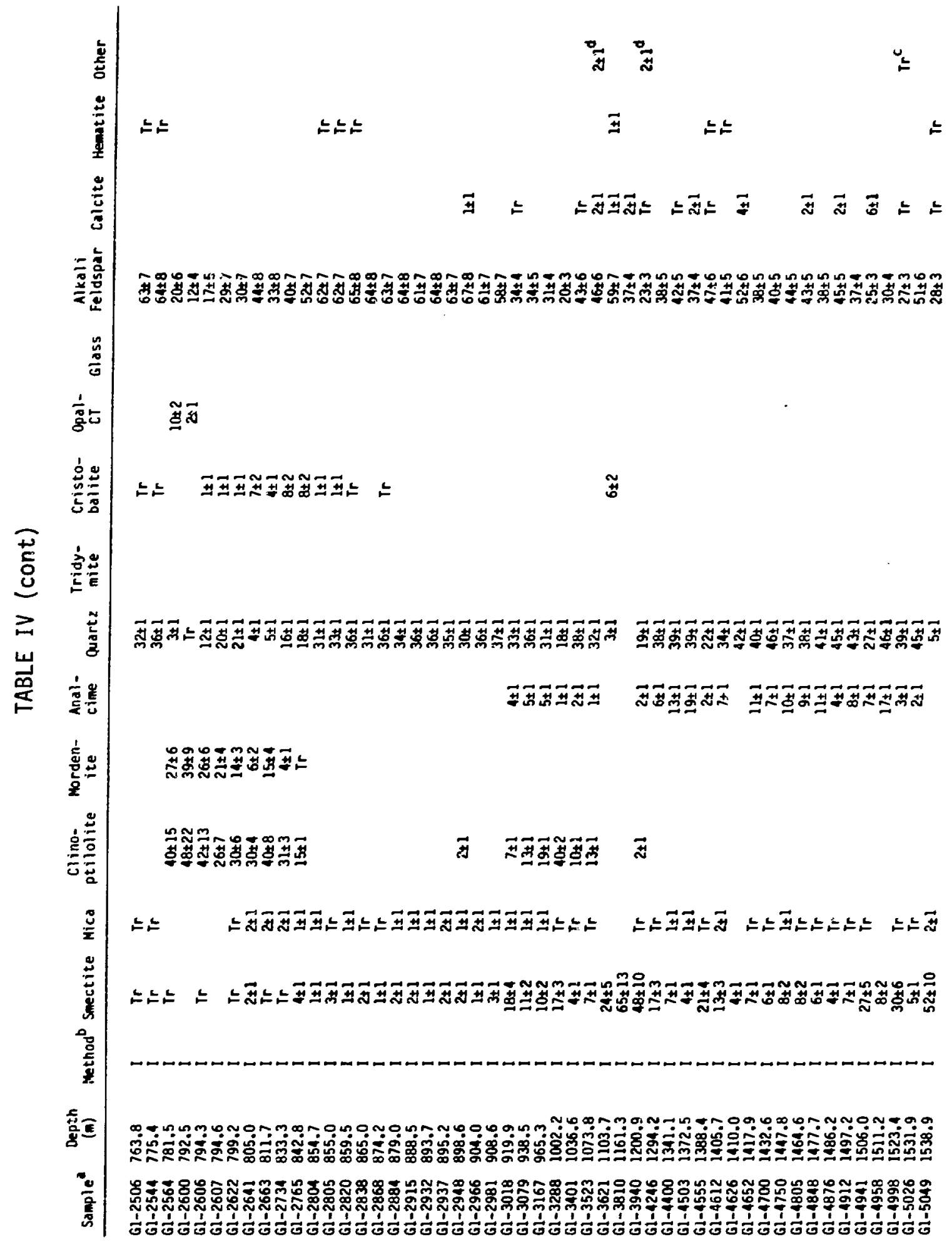




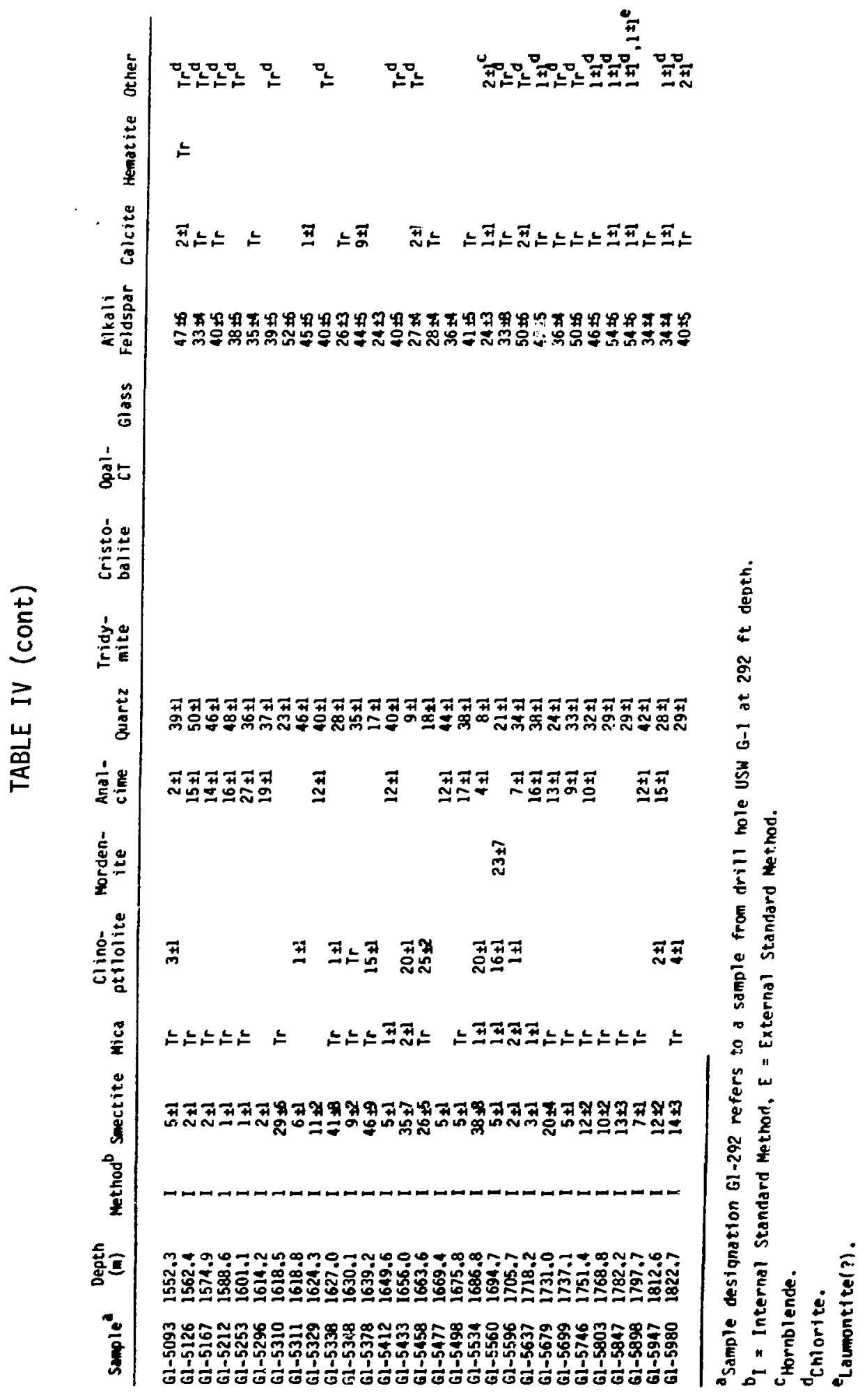




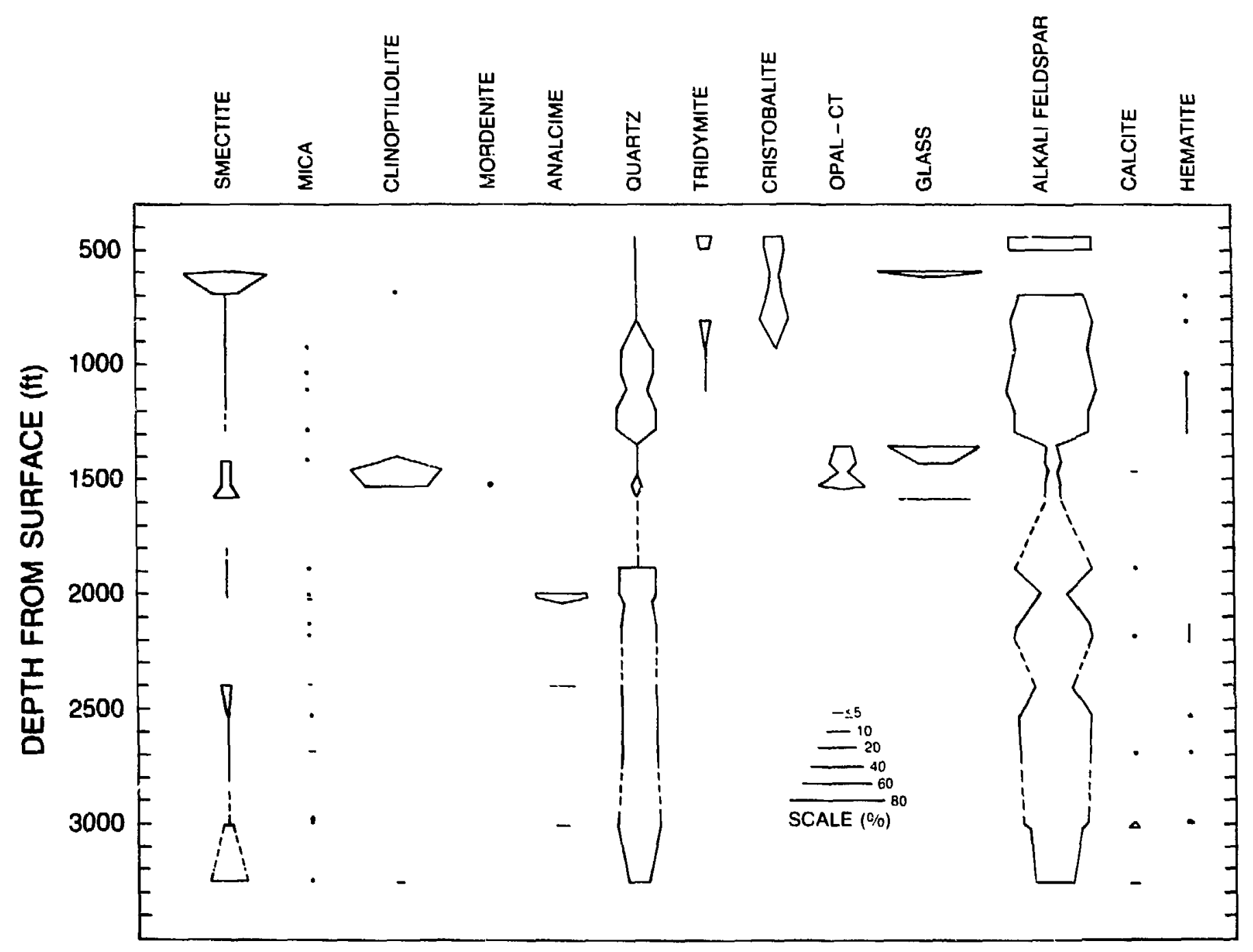

Fig. 3.

Graphical representation of the data in Table II showing the relative abundances of minerals and glass in drill core $\mathrm{J}-13$. The scale can be used to estimate relative weight percentages. 


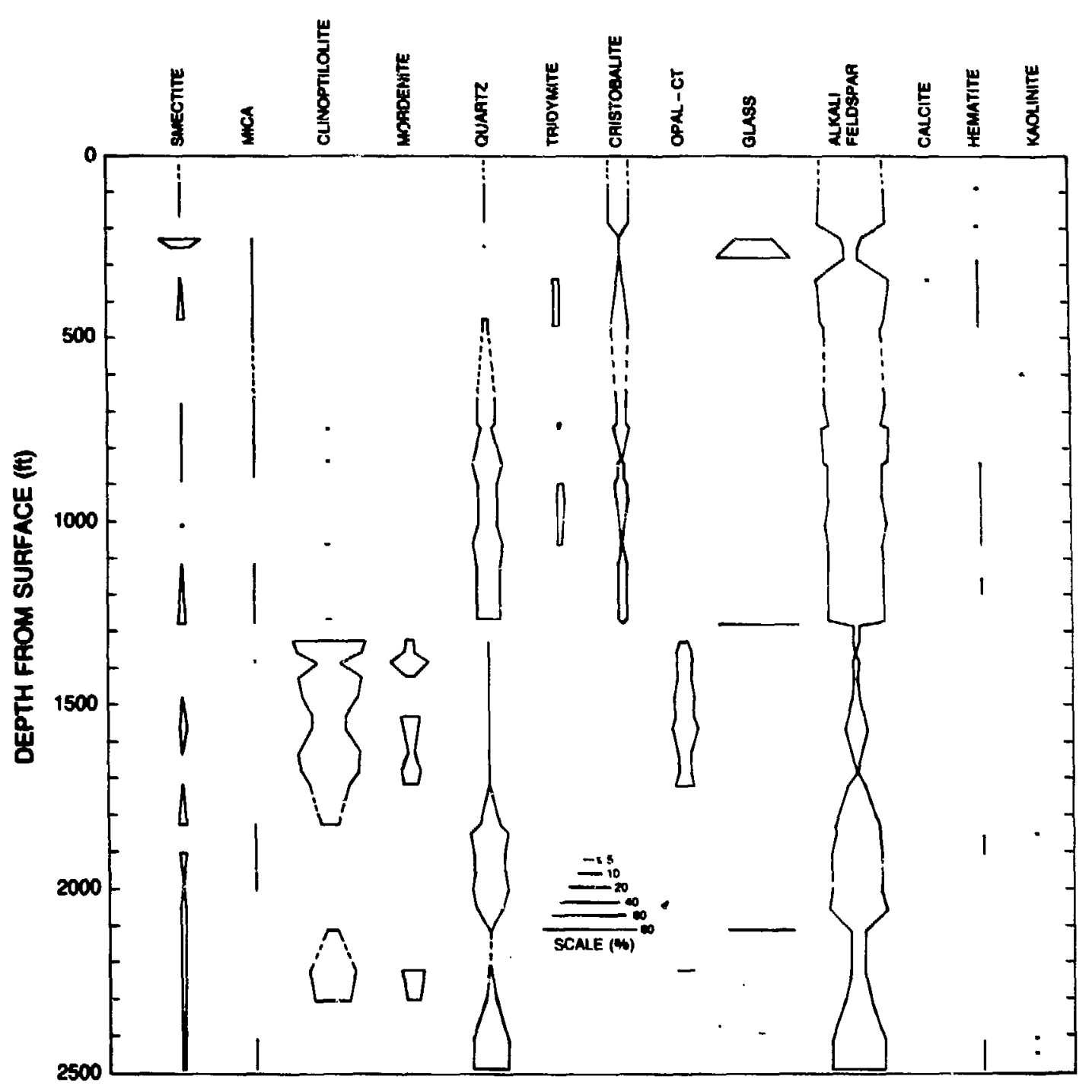

Fig. 4.

Graphical representation of the data in Table III showing the relative abundances of minera?s and glass in $\exists$ dril1 core UE-25A\#1. The scale can be used to estimate relative weight percentages. 


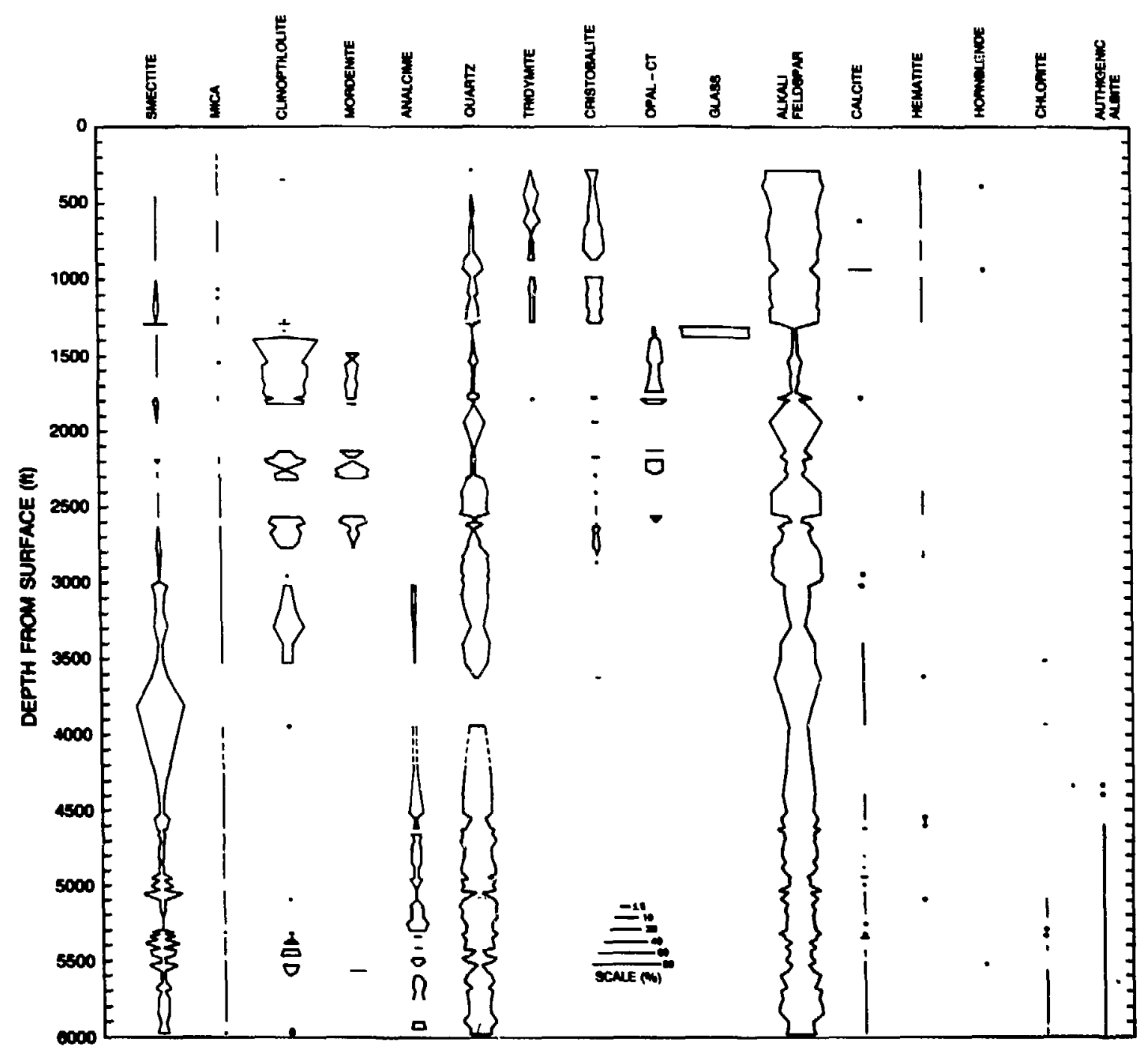

Fig. 5.

Graphical representation of the data in Tabie IV showing the relative abundances of minerals and glass in drill core USW G-1. The scale can be used to estimate relative weight percentages. Occurrences of authigenic albite are from Bish et a1. (1981). 
the identification of small amounts of calcite and hematite in the rocks. These are minerals that are potentially important in affecting the $c h-p H$ conditions of groundwater.

Heiken and Bevier (1979) reported the occurrence of phillipsite and erionite in several samples of $\mathrm{J}-13$ core, based upon electron microprobe data and an XRD identification listed as "erionite(?)." We did not find any evidence for phillipsite or erionite in J-13 core (see Bish and Vaniman 1985, pp. $11-12)$.

B. UE-25A\#1

The original analyses of UE-25A\#1 core (Sykes et al. 1979) were purely qualitative and lacked several important phases including smectite, tridymite, mordenite, opal-CT, much clinoptilolite, and calcite. The most recent analyses of the Topopah Spring Member in UE-25A\#1 (Carroll et al. 1981) are very similar to the results presented here, although tridymite and traces of clinoptilolite in some samples were not identified, and quartz appears to be too high in all previous analyses. The present report essentially supplements the earlier analyses of Carroll et al. (1981) and contains data on deeper core samples.

A noteworthy difference between the earlier results of Sykes et al. (1979) and the present data is the lack of erionite. Sykes et al. reported feathery crystals "tentatively identified as erionite" based on SEM examination of UE-25A\#1-1358 (413.9 m). Our analysis did not confirm their identification of erionite; recent SEM examinations of mordenite-bearing rocks yielded photographs of mordenite similar in appearance to the sykes et al. erionite (Caporuscio et al. 1982; Carlos 1985). Using XRD, we have, hnwever, recently identified erionite as a fracture-lining mineral in UE-25A\#1-1296 (395.0 m) (Bish and Vaniman 1985).

C. USW G-1

The mineralogical analyses of USW G-1 drill core presented in Bish et al. (1981) were obtained using the Siemens $x$-ray diffractometer, but integrated intensities were not measured, and no intensity standards were used. Therefore, the resultant data are semiquantitative at best. The qualitative agreement between the data in Bish et al. (1981) and our present analyses is fairly good, but the precision of our new data is superior to that of the older data, and several notable discrepancies exist. As with the $\mathrm{J}-13$ analyses, the present data for cristobalite are quite different from the original analyses. 
Bish et al. (1981) reported cristobalite occurring to the bottom of USW G-1, whereas our present data show that cristobalite is a major phase only to 842.8 $m(2765 \mathrm{ft})$. As poirited out above, the distribution of cristobalite has implications for the reaction of clinoptilolite to analcime because it appears that the aqueous silica activity controls this reaction. our present analyses also reveal the presence of significant opal-CT in zeolitized horizons. Furthermore, the new data show the presence of trace amounts of clinoptilolite and significant amounts of mordenite not previously recognized, a noteworthy difference considering the importance of clinoptilolite and mordenite as sorptive phases in Yucca Mountain tuffs. Bish et a1. (1981) reported kaolinite in the deeper portions of the USW G-1 drill hole, but the new data support instead the occurrence of chlorite at $1073.8 \mathrm{~m}(3523 \mathrm{ft})$ and deeper. However, differentiation between chlorite and kaolinite in these rocks is difficult. In addition to these differences, we also found small amounts of hematite throughout the core and hornblende in a few samples. Our data suggest that laumontite may be present in small amounts at $1782.2 \mathrm{~m}(5847 \mathrm{ft})$, but the data do not support an unambiguous determination.

IV. SUMMARY

New quantitative $x$-ray powder diffraction analyses of drill core from J-13, UE- $\angle 5 A \# 1$, and USW G-1 reveal significant differences from previous qualitative and semiquantitative analyses. The differences are most pronounced for J-13 and for the early UE-25A\#1 results (Heiken and Bevier 1979; Sykes et a1. 1979), whereas the more recent UE-25A\#1 data (Carroll et al. 1981 ) and the USW G-1 results (Bish et al. 1981) are qualitatively similar to the present iesults.

Several additional phases were identified in the core from these drill holes, including significant smectite, tridymite, cristobalite, opal-CT, and glass with minor calcite and hematite in J-13, tridymite and clinoptiloite in UE-25A\#1, and significant opal-CT and mordenite and minor clinoptilolite, calcite, and hematite in USW G-1. We found no evidence for phillipsite or erionite in J-13 core nor evidence for erionite in UE-25A\#1 core. Our new data do suggest, however, that laumontite may be present near the bottom of USW G-1. In addition, the new inalyses show that cristobalite is a major phase in G-1 only to about $842.8 \mathrm{~m}$, in contrast to earlier results showing cristobalite to the bottom of the hole. The material reported as kaolinite in 
USW G-1 appears to be chlorite, occurring sporadically below $1073.8 \mathrm{~m}$. Kaolinite was unambiguously identified in several samples from UE-25A\#1.

These differences are noteworthy for several reasons. It is important to know the distribution of smectite, clinoptilolite, ard mordenite within the exploration block because these minerals have relatively high sorption capacities for cationic radionuclides. In addition, these minerals, plus opal-CT and glass, are also subject to significant modification (dehydration, recrystallization: under the anticipated thermal load near the repository. Available geochemical and mineralogical data suggest that the distribution of clinoptilolite is influenced by the aqueous silica activity (Bish 1986). The distribution of cristobalite and tridymite is therefore quite important if we are to understand and predict the clinoptilolite distribution because solutions in equilibrium with cristobalite, tridymite, opal-CT, or glass have a silica activity considerably higher than solutions in equilibrium with quartz. The observed cristobalite-tridymite-clinoptilolite distribution in USW G-1 supperts the premise that aqueous silica activity is the controlling variable in the clinoptilolite-to-analcime reaction.

\section{ACKNOWLEDGMENTS}

We are grateful to D. T. Vaniman, R. Raymond, and D. Krier for insightful reviews of this manuscript and to $B$. Hahn for typing the manuscript.

\section{REFERENCES}

Bish, D. L., "Evaluation of Past and Future Alterations in Tuff at Yucca Mountain, Nevada, Based on the Clay Mineralogy of Drill Cores USW G-1, G-2, and G-3," Los Alamos National Laboratory report LA-10667-MS (1986).

Bish, D. L., F. A. Caporuscio, J. F. Copp, B. M. Crowe, J. D. Purson, J. R. Smyth, and R. G. Warren, "Preliminary Stratigraphic and Petrologic Characterization of Core Samples from USW-G1, Yucca Mountain, Nevada," LoS Alamos National Laboratory report LA-8840-MS (November 1981).

Bish, D. L., and D. T. Vaniman, "Mineralogic Summary of Yucca Mountain, Nevada," Los Alamos National Laboratory report LA-10543-MS (October 1985).

Bish, D. L., D. T. Vaniman, F. M. Byers, Jr., and D. E. Broxton, "Summary of the Mineralogy-Petrology of Tuffs of Yucca Mountain and the SecondaryPhase Thermal Stability in Tuffs," Los Alamos National Laboratory report LA-9321-MS (November 1982). 
Caporuscio, F. A., D. T. Vaniman, D. L. Bish, D. E. Broxton, B. Arney, G. H. Heiken, R. Gooley, and R. E. Semarge, "Petrologic Studies of Drill cores USW-G2 and UE25b-1H, Yucca Mountain, Nevada," Los Alamos National Laboratory report LA-9255-MS (July 1982).

Carlos, B. A., "Minerals in Fractures of the Unsaturated Zone from Drill core USW G-4, Yucca Mountain, Nye County, Nevada," Los Alamos National Laboratory report LA-10415-MS (May 1985).

Carroll, P. I., F. A. Caporuscio, and D. L. Bish, "Further Description of the Petrology of the Topopah Spring Member of the Paintbrush Tuff in Drill Holes UE25A-1 and USW-GI and of the Lithic-Rich Tuff in USW-G1, Yucca Mountain, Nevada," Los Alamos National Laboratory report LA-9000-MS (November 1981).

Chung, F. H., "Quantitative Interpretation of X-Ray Diffraction Patterns of Mixtures. I. Matrix-Flushing Method for Quantitative Multicomponent Analysis," Journal of Applied Crystallography 7 , 519-525 (1974a).

Chung, F. H., "Quantitative Interpretation of X-Ray Diffraction P.tterns of Mixtures. II. Adiabatic Principle of X-Ray Diffraction Analysis of Mixtures," Journal of Applied Crystallography Z, 526-531 (1974b).

Heiken, G. H., and M. L. Bevier, "Petrology of Tuiff Units from the J-13 Drill Site, Jackass Flats, Nevada," Los Al amos Scientific Laboratory report LA-7563-MS (February 1979).

Kerrisk, J. F., "Reaction-Path Calculations of Groundwater Chemistry and Mineral Formation at Rainier Mesa, Nevada," Los Alamos : National Laboratory report LA-9912-MS (December 1983).

Klug, H. P., and L. E. Alexander, X-ray Diffraction Procedures for Polycrystalline and Amorphous Materials, John Wiley \& Sons, Inc., New York (1974).

Smith, D. K., M. C. Nichols, and M. E. Zolensky, "POWD10, A FORTRAN IV Program for Calculating X-Ray Powder Diffraction Patterns - Version 10," Pennsylvania State University, College of Earth and Mineral Sciences report (May 1982).

Sykes, M. L., G. H. Heiken, and J. R. Smyth, "Mineralogy and Petrology of Tuff Units from the UE25a-1 Drill Site, Yucca Mountain, Nevada," Los Alamos Scientific Laboratory report LA-8139-MS (November 1979). 